\title{
IN VITRO IMMUNOSTIMULATION ACTIVITY OF NIGELLA SATIVA LINN. AND PSORALEA CORYLIFOLIA LINN. SEEDS USING A MURINE MACROPHAGE CELL LINE
}

\author{
SHEIK NOOR MOHAMED M, JAIKUMAR K, MARIMUTHU S, JOHN WYSON W, ANAND D, SARAVANAN P*
}

Department of Botany, Ramakrishna Mission Vivekananda College (Autonomous), Mylapore, Chennai - 600 004, Tamil Nadu, India. Email: sarviveka@gmail.com

Received: 18 November 2016, Revised and Accepted: 01 December 2016

\section{ABSTRACT}

Objective: The aim of this study is to analyze the phytochemical constituents and the in vitro immunomodulatory potential of ethanol extract of Nigella sativa and Psoralea corylifolia seeds.

Methods: Phytoconstituents in the ethanol extract of $N$. sativa and P. corylifolia seeds were analyzed using gas chromatography and mass spectrum and their immunomodulatory activity was investigated in vitro by cell proliferation assay with J774A.1 cell line.

Results: Thirteen biochemical constituents have been identified with ethanol extract of $N$. sativa and nine from the P. corylifolia. The maximum relative activity of $138.77 \pm 0.44 \%$ cell proliferation was expressed at $25 \mu \mathrm{g} / \mathrm{ml}$ by $N$. sativa and $80.70 \pm 0.42 \%$ of proliferation by $P$. corylifolia at $25 \mu \mathrm{g} / \mathrm{ml}$.

Conclusion: The results suggest that the ethanol extract of the plant seeds have stimulating activity on macrophage cells and could be useful for modulating immune functions.

Keywords: Immunomodulatory, Cell proliferation, Macrophage cell line, Nigella sativa, Psoralea corylifolia.

(C) 2017 The Authors. Published by Innovare Academic Sciences Pvt Ltd. This is an open access article under the CC BY license (http://creativecommons. org/licenses/by/4. 0/) DOI: http://dx.doi.org/10.22159/ajpcr.2017.v10i3.16227

\section{INTRODUCTION}

The immune system is a remarkably versatile defense system that has evolved to protect animals from invading pathogenic microorganisms and to eliminate diseases. The function and the efficacy of immune system may be influenced by many exogenous factors such as food and pharmaceuticals, physical and psychological stress and hormones. Resulting in either immunostimulation or immunosuppression [1]. Suppression in immune response disrupts host's ability to defend itself against bacteria, viruses, and parasites. Immunomodulation using plant material can provide an alternative to conventional chemotherapy for a variety of diseases, especially when the host defense mechanism has to be activated under the condition of impaired immune response [2]. A large number of drugs in use are derived from plants, like morphine from Papaver somniferum, Aswagandha from Withania somnifera, Ephedrine from Ephedra vulgaris, Atrophine from Atropa belladonna, etc. [3]. The phytochemical constituents like terpenoids, steroids, proteins, and tannins [4] are considered to exhibit this immunomodulatory property.

A large number of plants with therapeutic potentials have been considered. One such is Nigella sativa Linn. (Ranunculaceae), commonly known as "black cumin," is an herbaceous plant that grows in Mediterranean countries. The oil and seed constituents have shown potential medicinal properties in traditional medicine [5]. The black seeds contain $36-38 \%$ fixed oil, with proteins, alkaloids, saponins, and essential oils making up the rest of the composition [6]. Black seed extract has been reported to possess antimicrobial activity [7], antitumor activity [8], and a stimulatory effect on the immune system [9]. Psoralea corylifolia Linn. commonly known as "Bakuchi" is conventionally used in ayurvedic system of medicine for the treatment of various kinds of human disorders but especially for treatment of skin disorders [10]. P. corylifolia seed has been reported to contain several phytoconstituents and possess antibacterial, antifungal, antioxidant, antiflarial, estrogenic, and immunomodulatory activity [11]. However, there is no scientific data on the in vitro immunomodulatory activity of these plants. Therefore the aim of the present study is to identify the bioactive components of these plants by subjecting the ethanol extracts of the plant seeds to gas chromatography and mass spectrum (GC-MS) analysis and to investigate their immune stimulation potential using an in vitro cell line model.

\section{METHODS}

Collection of plant materials

Seeds of N. sativa and P. corylifolia were procured from herbal medicine store in Chennai. The seeds were authenticated at the Department of Medicinal Botany, National Institute of Siddha, Chennai and a voucher specimen (voucher number - NISMB2052015) was submitted.

\section{Preparation of plant extracts}

Fine seeds were cleaned and milled to a powder using a domestic blender. A total of $25 \mathrm{~g}$ of powdered seeds were then subjected to soxhlet extraction with $250 \mathrm{ml}$ of ethanol as solvent. The seed extract was concentrated using vacuum rotatory evaporation to void of solvent. The extracts were filter sterilized and stored at $4^{\circ} \mathrm{C}$ until further use $[12,13]$.

\section{Cell culture}

J774A.1, a murine macrophage cell line, was procured from National Centre for Cell Science, Pune, Maharashtra, India. The cells were maintained in Dulbecco's modified Eagle's medium (DMEM) supplemented with $10 \%(\mathrm{v} / \mathrm{v})$ inactivated fetal bovine serum (FBS), 100 units $/ \mathrm{ml}$ of penicillin, $100 \mu \mathrm{g} / \mathrm{ml}$ of streptomycin and $3 \%$ L-glutamine (Himedia Labs, Mumbai). The cells were incubated at $37^{\circ} \mathrm{C}$ in a humidified atmosphere containing $5 \%(\mathrm{v} / \mathrm{v})$ carbon dioxide $\left(\mathrm{CO}_{2}\right)$. The medium was changed every 2 days, and the cells were serially passaged biweekly [14].

\section{Treatment of cell cultures with ethanol extracts}

A volume of $100 \mu \mathrm{l}$ of medium containing $1 \times 10^{5}$ cells were seeded triplicates in 96 -well plates. The plates were incubated for $24 \mathrm{hrs}$ at 
$37^{\circ} \mathrm{C}$ in $5 \% \mathrm{CO}_{2}$. After incubation, the old medium was decanted and all the plates were replenished with fresh DMEM medium supplemented with $10 \%$ FBS. The cells were then treated with varying concentrations $(6.25,12.5,25,50$, and $100 \mu \mathrm{g} / \mathrm{ml})$ prepared by diluting the extract in DMEM and then incubated. The effect of ethanol extracts on macrophage proliferation was evaluated with wells containing only cells as a negative control and compared to cells treated with concanavalin-A (Con-A), positive control [15]

Cell proliferation assay using (3-(4,5-dimethylthiazol-2-Yl)-2,5diphenyltetrazolium bromide) (MTT) reagent

After incubation, $20 \mu \mathrm{l}$ of MTT reagent $(5 \mathrm{mg} / \mathrm{ml}$ in phosphate buffer saline) was added to each well and further incubated for $4 \mathrm{hrs}$ at $37^{\circ} \mathrm{C}$. Then, dimethyl sulfoxide was added to dissolve the formazon crystals, intensity of the colored reaction product was measured at $540 \mathrm{~nm}$ using Microplate Reader (BIOTEK, USA) [16]

\section{GC-MS analysis}

GC-MS analysis of the ethanol extract of $N$. sativa and P. corylifolia was carried out with $2 \mu \mathrm{l}$ of extract employed on a GC clarus 500 Perkin Elmer system comprising a AOC-20i auto sampler and gas chromatograph interfaced to a mass spectrometer (GC-MS) instrument employing the following conditions: Column Elite-1 fused silica capillary column $(30 \times 0.25 \mathrm{~mm}$ ID $\times 1 \mathrm{EM} \mathrm{df}$, composed of $100 \%$ dimethyl polysiloxane), operating in electron impact mode at $70 \mathrm{eV}$; helium (99.999\%) was used as carrier gas at a constant flow of $1 \mathrm{ml} / \mathrm{min}$ and an injection volume of $0.5 \mathrm{EI}$ was employed (split ratio of $10: 1$ ) injector temperature $250^{\circ} \mathrm{C}$; ion source temperature $280^{\circ} \mathrm{C}$. The oven temperature was programmed from $110^{\circ} \mathrm{C}$ (isothermal for 2 minutes), with an increase of $10^{\circ} \mathrm{C} /$ minutes, to $200^{\circ} \mathrm{C} /$ minutes, then $5^{\circ} \mathrm{C} /$ minutes to $280^{\circ} \mathrm{C} /$ minutes, ending with a 9 minutes isothermal at $280^{\circ} \mathrm{C}$. MS were taken at $70 \mathrm{eV}$; a scan interval of $0.5 \mathrm{~s}$ and fragments from 40 to $550 \mathrm{Da}$. The MS of the unknown component was compared with the spectrum of the known components stored in The National Institute of Standards and Technology (NIST) library $[17,18]$. The name, molecular weight, and structure of the components of the test materials were ascertained.

\section{Statistical analysis}

The data were analyzed using one-way analysis of variance (one-way ANOVA). Results expressed as mean \pm standard deviation for triplicate assays using Graph Pad Prism software. Values of $p<0.05$ were the criteria for statistical significance.

\section{RESULTS}

The GC-MS analysis of the ethanol extract of $N$. sativa seeds revealed the presence of 13 peaks (Fig. 1) and P. corylifolia showed 9 peaks (Fig. 2) indicating the presence of phytoconstituents whose name, molecular weight and structure were identified and characterized on comparison with data in the NIST library (Tables 1 and 2).

\section{Cell proliferation assay}

Ethanol extract of $N$. sativa showed a maximum relative activity of $138.77 \pm 0.44 \%$ at $25 \mu \mathrm{g} / \mathrm{ml}$ compared to the standard drug (Con- $\mathrm{A}$ ) which expressed a proliferation rate of $51.11 \pm 0.96 \%$. $11.30 \pm 0.24$, $112.03 \pm 0.15,138.77 \pm 0.44,83.46 \pm 0.30$ and $50.54 \pm 0.43 \%$ increase in the proliferation of macrophage cells were reported at the dose rate of 6.25 , $12.5,25,50$, and $100 \mu \mathrm{g} / \mathrm{ml}$ of ethanol extract, respectively (Fig. 3). The ethanol extract of $P$. corylifolia showed a maximum relative activity of $80.70 \pm 0.42 \%$ at $25 \mu \mathrm{g} / \mathrm{ml}$ compared to the standard (Con-A), resulting in the proliferation range of $10.17 \pm 0.76,28.46 \pm 0.46,80.70 \pm 0.42$, $38.02 \pm 0.55$, and $12.16 \pm 0.23 \%$ between varying concentrations of 6.25 , 12.5, 25, 50, and $100 \mu \mathrm{g} / \mathrm{ml}$ (Fig. 4).

\section{DISCUSSION}

The information regarding the chemical constituents of a plant is generally provided by the qualitative phytochemical screening of its extract. Hence, the GC-MS analysis was opted to assess the phytochemical constituents present in the ethanol extracts of the seeds. Among the 13 components characterized from the GC-MS analysis of $N$. sativa. 9,12-octadecadienoic, ethyl ester was identified as a major chemical constituent $(50.98 \%)$ followed by Hexadecanoic acid, ethyl ester (19.63\%) and 8-octadecenoic acid, methyl ester,(E)- (14.56\%) in the ethanol extract of N. sativa. Phenol, 4-(3,7-dimethyl-3-ethenylocta-1,6-dienyl)- (45.99\%) and Linoleic acid ethyl ester (45.99\%) was identified as the major chemical constituent in the ethanol extract of P. corylifolia. Other components in trace amounts were also present in the ethanol extract of both plant seeds analyzed.

The immunomodulatory effect in the cell proliferation model has been a target of study in the search for new therapeutic agents of natural origin $[19,20]$. Although various components have been screened for their immunomodulatory potential using cell line as a model, in this study, immune stimulating activity of ethanol extract of $N$. sativa and

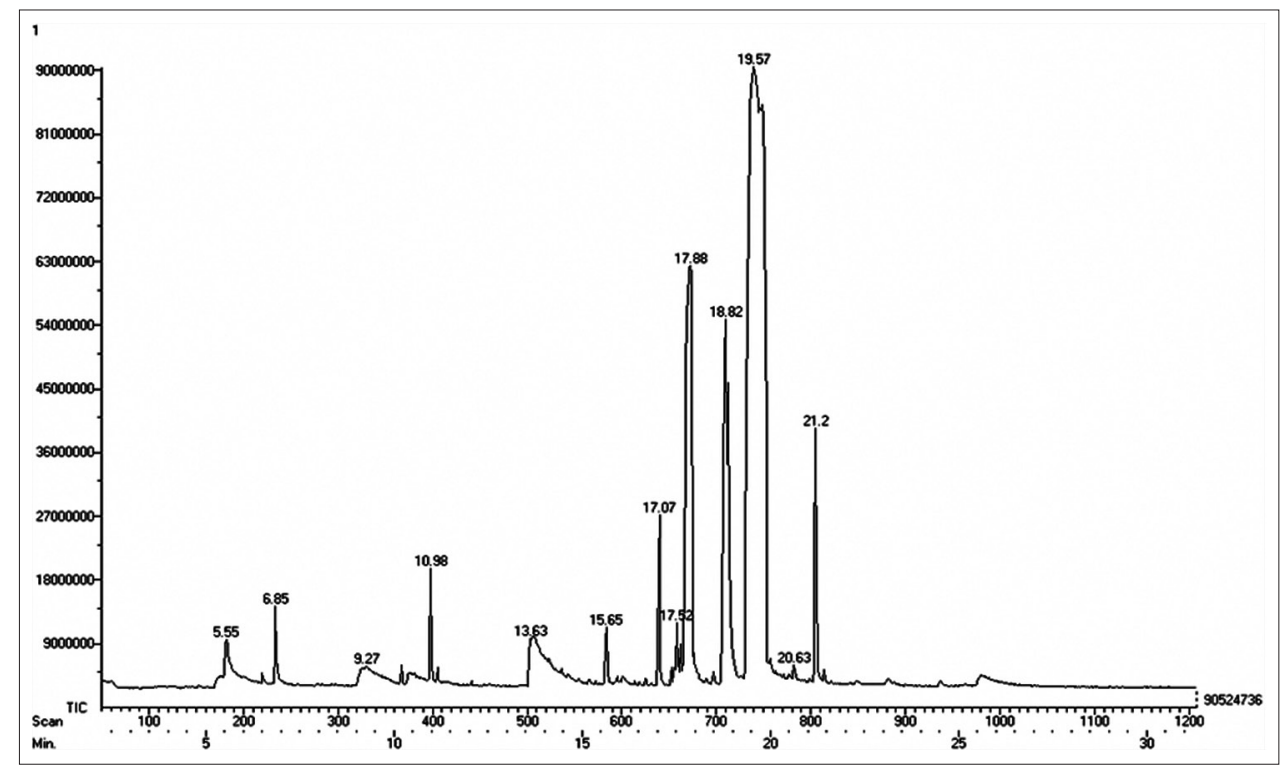

Fig. 1: Chromatogram of ethanol extract of Nigella sativa seed by gas chromatography and mass spectrum 
Table 1: Chemical composition (\%) of ethanol extract of Nigella sativa seed

\begin{tabular}{|c|c|c|c|c|c|}
\hline S. No. & Name of the compound & Retention time & Peak \% & Molecular weight $\mathrm{g} / \mathrm{mol}$ & $\begin{array}{l}\text { Chemical } \\
\text { formula }\end{array}$ \\
\hline 1 & o-cymol & 5.5 & 1.66 & 134.21 & $\mathrm{C}_{10}$ \\
\hline 2 & Ether, p-menth-6-en-2-yl methyl & 6.85 & 1.13 & 168.27 & $\mathrm{C}_{11} \mathrm{H}_{20} \mathrm{H}^{14} \mathrm{O}$ \\
\hline 3 & $(+)$-Longifolene & 10.98 & 0.99 & 204.35 & $\mathrm{C}_{15} \mathrm{H}_{24}$ \\
\hline 4 & Pentadecanoic acid, 14-methyl-, methyl ester & 17.08 & 2.34 & 270.45 & $\mathrm{C}_{17} \mathrm{H}_{34}^{24} \mathrm{O}_{2}$ \\
\hline 5 & 8-Octadecenoic acid, methyl ester,(E)- & 18.82 & 14.56 & 296.48 & $\mathrm{C}_{19} \mathrm{H}_{36}^{34} \mathrm{O}_{2}^{2}$ \\
\hline 6 & 9,12-Octadecadienoic, ethyl ester & 19.57 & 50.98 & 308.49 & $\mathrm{C}_{20}{ }_{20} \mathrm{H}_{36}^{30} \mathrm{O}_{2}^{2}$ \\
\hline 8 & 1-Tetradecene, 2-decyl- & 21.23 & 3.42 & 336.63 & $\mathrm{C}_{24} \mathrm{H}_{48}^{38}$ \\
\hline 9 & 2,5-Cyclohexadiene-1,4-dione, 2-methyl-5-(1-methylethyl)- & 9.27 & 1.03 & 164.20 & $\mathrm{C}_{10}^{24} \mathrm{H}_{12}^{40} \mathrm{O}_{2}$ \\
\hline 10 & Durohydroquinone & 13.7 & 2.40 & 166.22 & $\mathrm{C}_{10} \mathrm{H}_{14} \mathrm{O}_{2}^{2}$ \\
\hline 11 & Ethyl 9-hexadecenoate & 17.52 & 0.90 & 282.46 & $\mathrm{C}_{18}^{10} \mathrm{H}_{34}^{14} \mathrm{O}_{2}^{2}$ \\
\hline 12 & Hexadecanoic acid, ethyl ester & 17.93 & 19.63 & 284.47 & $\mathrm{C}_{18} \mathrm{H}_{36} \mathrm{O}_{2}$ \\
\hline 13 & Tetradecanoic acid, ethyl ester & 15.65 & 0.83 & 256.42 & $\mathrm{C}_{16}^{18} \mathrm{H}_{32}^{30} \mathrm{O}_{2}^{2}$ \\
\hline
\end{tabular}

Table 2: Chemical composition (\%) of ethanol extract of Psoralea corylifolia seed

\begin{tabular}{|c|c|c|c|c|c|}
\hline S. No. & Name of the compound & Retention time & Peak \% & Molecular weight $\mathrm{g} / \mathrm{mol}$ & Chemical formula \\
\hline 1 & Caryophyllene & 11.50 & 1.81 & 204.35 & $\mathrm{C}_{15} \mathrm{H}$ \\
\hline 2 & Epoxycaryophyllene & 13.32 & 1.92 & 220.35 & $\mathrm{C}_{15}^{15} \mathrm{H}_{24}^{24} \mathrm{O}$ \\
\hline 3 & Estra-1,3,5 (10)-trien-17a-ol & 17.77 & 1.13 & 286.40 & $\mathrm{C}_{19}^{15} \mathrm{H}_{26}^{24} \mathrm{O}_{2}$ \\
\hline 4 & 9,12-Octadecadienoic acid (Z, Z)-, methyl ester & 18.75 & 1.91 & 294.47 & $\mathrm{C}_{19}^{19} \mathrm{H}_{34}^{26} \mathrm{O}_{2}^{2}$ \\
\hline 5 & Phenol,4-(3,7-dimethyl-3-ethenylocta-1,6-dienyl)- & 19.30 & 45.99 & 256.38 & $\mathrm{C}_{18} \mathrm{H}_{24}^{34} \mathrm{O}^{2}$ \\
\hline 6 & Linoleic acid ethyl ester & 19.45 & 45.99 & 308.49 & $\mathrm{C}_{20}^{18} \mathrm{H}_{36}^{24} \mathrm{O}_{2}$ \\
\hline 7 & 11-Eicosenoic acid, methyl ester & 20.60 & 0.85 & 324.54 & $\mathrm{C}_{21}^{20} \mathrm{H}_{40}^{36} \mathrm{O}_{2}^{2}$ \\
\hline 9 & Ethyl 13-docosenoate (ethyl erucate) & 23.28 & 0.34 & 366.62 & $\mathrm{C}_{24}^{23} \mathrm{H}_{46}^{44} \mathrm{O}_{2}^{2}$ \\
\hline
\end{tabular}

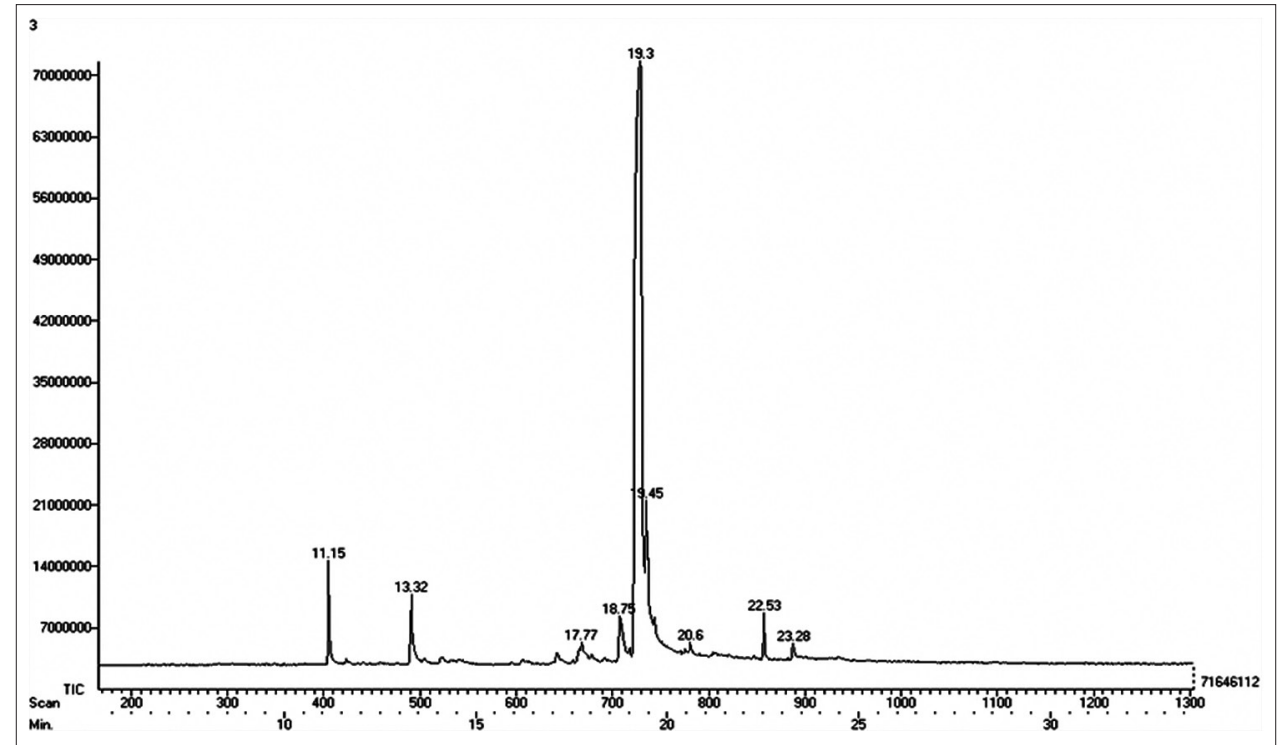

Fig. 2: Chromatogram of ethanol extract of Psoralea corylifolia seed by gas chromatography and mass spectrum

P. corylifolia have been screened using J774A.1 cell line. Ethanol extract of $N$. sativa and $P$. corylifolia seeds assessed for cell proliferation assay, induced an increase in cell proliferation depending on the varying concentrations. In previous reports, 6-carboxymethylthiopurine, an anti-inflammatory drug and the hot-water extract of Sargassum hemiphyllum was reported to stimulate proliferation of J774A.1 cell $[21,22]$. The proliferation stimuli were dose dependent in earlier reports, where maximum proliferation was obtained from higher concentration. The reports were in contrast to the current study where the extract at its maximum and minimum concentration had a varying effect on the macrophage cells. Percentage of proliferation was comparatively lower at both concentration. The present observation might be due to toxic nature of the analyzed samples at higher concentration while the minimum concentration would have had a negligible effect on cell duplication.

Present results indicate that the tested ethanol extract of $N$. sativa and $P$. corylifolia are capable of stimulating the immune function by increasing the proliferation rate of macrophages. Purification and isolation of the component responsible for activity were required to void the toxic component in the crude extract to construct potential immunomodulator agent.

\section{CONCLUSION}

The phytochemical analyze concludes that $N$. sativa and P. corylifolia seed extract contain various bioactive compounds. The study is evident 


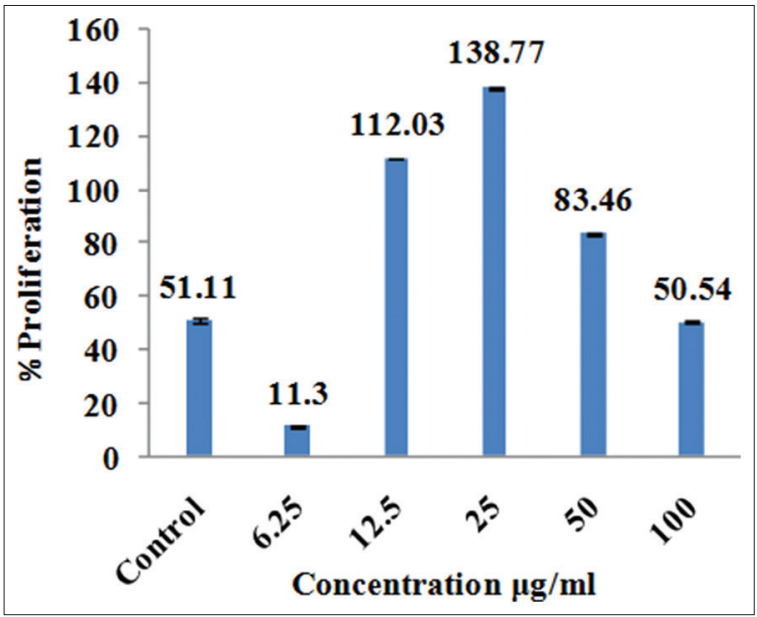

Fig. 3: The stimulating effect of the ethanol extract of Nigella sativa on J774A.1 cells. The data plotted represent mean \pm standard deviation of triplicate experiments $(n-3) . p<0.05$



Fig. 4: The stimulating effect of the ethanol extract of Psoralea corylifolia on J774A.1 cells. The data plotted represent mean \pm standard deviation of triplicate experiments (n-3). $p<0.05$

that ethanol extract of $N$. sativa and $P$. corylifolia played an important role in the modulation of the immune response and thus may have application as an immunomodulatory agent.

\section{ACKNOWLEDGMENTS}

The authors are thankful to the Secretary and the Principal, Ramakrishna Mission Vivekananda College (Autonomous), Mylapore, Chennai, India for providing all facilities and we especially thank Sophisticated Analytical Instrument Facility, Indian Institute of Technology, Chennai, India for carrying out GC-MS studies and validation of the results.

\section{REFERENCES}

1. Patil VV, Bhangale CS, Patil RV. Studies on immunomodulatory activity of Ficus carica. Int J Pharm Pharm Sci 2010;2(4):97-9.

2. Chitra V, Janaki PS, Raju D, Rao PV. Evaluation of immunomodulatory activity of ethanolic extract of leaves of Glycosmis pentaphylla in Swiss albino mice. Int J Pharm Pharm Sci 2013;5(4):110-3.

3. Bhadoriya SS, Mangal A, Mandoriya N. Immunomodulatory effect of M. tricuspidatum. Int J Curr Pharm Res 2012;4(2):33-6.

4. Biswas K, Chattopadhyay I, Banerjee RK, Bandyopadhyay U. Biological activities and medicinal properties of neem (Azadirachta indica). Curr Sci 2002;82(11):1136-345.

5. Salem ML. Immunomodulatory and therapeutic properties of the Nigella sativa L. seed. Int Immunopharmacol 2005;5(13-14):1749-70.

6. Burits M, Bucar F. Antioxidant activity of Nigella sativa essential oil. Phytother Res 2000;14(5):323-8.

7. Morsi NM. Antimicrobial effect of crude extracts of Nigella sativa on multiple antibiotics-resistant bacteria. Acta Microbiol Pol 2000;49(1):63-74

8. Worthen DR, Ghosheh OA, Crooks PA. The in vitro anti-tumor activity of some crude and purified components of blackseed, Nigella sativa L. Anticancer Res 1998;18(3A):1527-32.

9. Salem ML, Hossain MS. In vivo acute depletion of CD $8(+)$ T cells before murine cytomegalovirus infection upregulated innate antiviral activity of natural killer cells. Int J Immunopharmacol 2000;22(9):707-18.

10. Siddhinandan M. Khadirarishta-Kushtharogadhikar. $54^{\text {th }}$ ed. Varanasi: Bhiashajya Ratnavali Chaukhambha Publication; 2009. p. 353-8.

11. Latha PG, Panikkar KR. Inhibition of chemical carcinogenesis by Psoralea corylifolia seeds. J Ethnopharmacol 1999;68(1-3):295-8.

12. Chanda S, Kaneria M, Nair R. Antibacterial activity of Psoralea corylifolia Linn. Seed and aerial parts with various extraction methods. Res J Microbiol 2011;6(2):124-31

13. Ozcan M. Inhibitory effects of spice extracts on the growth of Aspergillus parasiticus NRRL2999 strain. Z Lebensm Unters Forsch A 1998;2079(3):253-5.

14. Musso T, Badolato R, Ravarino D, Stornello S, Panzanelli O, Merlino C, et al. Interaction of Bartonella henselae with the murine macrophage cell line J774: Infection and proinflammatory response. Infect Immun 2001;69(10):5974-80.

15. Goel A. Immumological Studies on Fileriaris, Ph.D. Thesis. Lucknow, Uttar Pradesh, India: Central Drug Research Institute, (CDRI); 1991.

16. Snedecor GW, Cochran WG. Statistical Methods. $7^{\text {th }}$ ed. Ames, Iowa, USA: The Iowa State University; 1981.

17. Merlin NJ, Parthasarathy V, Manavalan R, Kumaravel S. Chemical investigation of aerial parts of Gmelina asiatica Linn. by GC-MS. Pharmacogn Res 2009;1(3):152-6.

18. Anand D, Wyson WJ, Saravanan P, Rajarajan S. Phytochemical analysis of leaf extract of Eclipta alba (L.) Hassk by GC-MS method. IJPPR 2014;6(3):562-6

19. Arokiyaraj S, Perinbam K, Agastian P, Balaraju K. Immunosuppressive effect of medicinal plants of Kolli Hills on mitogen-stimulated proliferation of the human peripheral blood mononuclear cells in vitro. Indian J Pharmacol 2007;39(4):180-3.

20. Sriwanthana B, Treesangsri W, Boriboontrakul B, Niumsakul S, Chavalittumrong P. In vitro effects of Thai medicinal plants on human lymphocyte activity. Songklanakarin J Sci Technol 2007;29(1):17-28.

21. De Paula ML, Braga FG, Coimbra ES, Carmo AM, Teixeira HC, Da Silva AD, et al. Modulatory effects of 6-carboxymethylthiopurine on activated murine macrophages. Chem Biol Drug Des 2008;71(6):563-7.

22. Hwang PA, Chwen-Herng WU, Gau SY, Chien SY, Hwang DF. Antioxidant and immune-stimulating activities of hot-water extract from Seaweed Sargassum hemiphyllum. JMST 2010;18(1):41-6. 